\title{
Rechtsmacht in de rechtspersoon
}

\author{
Twee arresten, één forum voor corporate geschillen?
}

\author{
$M r . K . A \cdot M$. van $V u g h t^{*}$
}

Welke rechter is bevoegd geschillen in een rechtspersoon te beslechten? Deze academisch ingestoken bijdrage bespreekt de arresten E.ON Czech/Dêdouch en Inversiones/Cancun II. Auteur bepleit een ruime uitleg van de exclusieve bevoegdheid van artikel 24 sub 2 EEX, zodanig dat een forum societatis in het verschiet ligt.

\section{Inleiding}

Ook onder de herschikte EEX-Verordening (Brussel Ibis) ${ }^{1}$ valt het niet mee om vast te stellen welke rechter bevoegd is binnen een rechtspersoon rijzende geschillen te beslechten. Een eenduidig forum societatis ontbreekt. De verhoudingen binnen een rechtspersoon laten zich nu eens als overeenkomst typeren, dan weer als onrechtmatige daad. In beide gevallen levert de toepassing van artikel 7 EEX de nodige hoofdbrekens op, omdat de overeenkomst of de onrechtmatige daad zich in de context van een rechtspersoon niet gemakkelijk laat lokaliseren. ${ }^{2}$ Daarbij komt dat de rechtspersoon soms tussen wal en schip valt. Artikel 7 EEX vindt dan geen toepassing, zodat moet worden teruggevallen op de rechter van de woonplaats van gedaagde, die overeenkomstig de hoofdregel van artikel 4 sub 1 EEX bevoegd is. ${ }^{3}$ Aldus hangt de rechtsmacht in de rechtspersoon niet noodzakelijkerwijs samen met de plaats waar die rechtspersoon is gevestigd. ${ }^{4}$ Niet zelden zal daardoor - ik chargeer enigszins - de drukbezette Italiaanse rechter te rade moeten gaan bij de Asser, het Compendium of de Groene Serie wanneer een Nederlandse rechtspersoon een Italiaanse aandeelhouder in rechte betrekt. Dit gebrek aan Gleichlauf tussen de bevoegde rechter en het toepasselijke recht moge tot

Mr. K.A.M. van Vught is promovendus aan het Van der Heijden Instituut (onderdeel van het OO\&R) van de Radboud Universiteit Nijmegen.

1. Verordening (EU) 1215/2012 van het Europees Parlement en de Raad van 12 december 2012 betreffende de rechterlijke bevoegdheid, de erkenning en de tenuitvoerlegging van beslissingen in burgerlijke en handelszaken (PbEU 2012, L 351/1). Ik verwijs hierna steeds naar de artikelnummers van deze herschikking.

2. Zie Joh. Weber, Gesellschaftsrecht und Gläubigerschutz im Internationalen Zivilverfahrensrecht, Tübingen: Mohr Siebeck 2011, p. 226 e.v., P. Paschalidis, Freedom of establishment and private international law for corporations, Oxford: Oxford University Press 2012/2.20-2.26 en P. Vlas, Rechtspersonen, Apeldoorn: Maklu 2017/191 e.v. Illustratief is de complexe rechtsmachtverdeling rondom bestuurdersaansprakelijkheid, zoals die blijkt uit HvJ EU 10 september 2015, JOR 2015/288 m.nt. Van der Plas (Holterman/Spies).

3. Zie A-G Wathelet, conclusie voor HvJ EU 7 maart 2018, JOR 2018/143 (E.ON Czech/Dêdouch), punt 23-26.

4. Voor nu daargelaten hoe die vestigingsplaats zich onder de EEX laat vaststellen; zie daarover Vlas 2017/178-183. vreugde strekken van uitgeverij Kluwer, bevredigend is het allerminst.

Maar hoe zit het dan met artikel 24 EEX? Inderdaad wijst artikel 24 sub 2 EEX een exclusief bevoegde rechter aan. De rechter van de plaats van vestiging heeft bij uitsluiting rechtsmacht over 'de geldigheid, de nietigheid of de ontbinding van vennootschappen of rechtspersonen (...), dan wel van de besluiten van hun organen'. Deze bepaling heeft naar de (zo meteen te bespreken) vaste jurisprudentie van het Europese Hof van Justitie evenwel een beperkte reikwijdte. Ook artikel 8 sub 3 EEX, een ander middel om geschillen binnen een vennootschap voor hetzelfde forum te brengen, kent zo zijn beperkingen. Artikel 8 sub 3 EEX voorziet erin dat een 'tegenvordering' met betrekking tot 'hetzelfde rechtsfeit' bij de rechter kan worden ingesteld die over de oorspronkelijke vordering oordeelt. Artikel 24 sub 2 en 8 sub 3 EEX kúnnen dus elk bewerkstelligen dat een vennootschappelijk geschil voor dezelfde rechter komt, maar slagen daarin niet steeds.

$\mathrm{Nu}$ lijken twee recente uitspraken het toepassingsbereik van beide bepalingen te verruimen. In de zaak E.ON Czech/ Dêdouch ${ }^{5}$ zet het Hof van Justitie een klein, voorzichtig stapje in de richting van een iets ruimhartigere uitleg van artikel 24 sub 2 EEX (par. 2). In Inversiones/Cancun $\mathrm{II}^{6}$ doet onze Hoge Raad iets soortgelijks, maar dan met betrekking tot artikel 8 sub 3 EEX (par. 3). De tendens in de jurisprudentie wijst dus in de richting van een meer 'samenhangende' rechtsmacht in de rechtspersoon. De vraag rijst in hoeverre geschillen in de rechtspersoon meer dan thans bij hetzelfde forum kunnen (en moeten) worden gecentreerd (par. 4). Hoe ver strekken de artikelen 24 en 8 EEX eigenlijk? En kan het nog een stukje verder?

\section{E.ON Czech/Dêdouch ${ }^{7}$}

\subsection{Casus}

E.ON Czech, een Duitse Aktiengesellschaft, bezit het leeuwendeel van de aandelen in de Tsjechische vennootschap Jihoces-

5. HvJ EU 7 maart 2018, JOR 2018/144 m.nt. J.H.L. Beckers (E.ON Czech/Dêdouch).

6. HR 8 december 2018, JOR 2018/143 m.nt. A. Knigge \& P. Sluijter (Inversiones/Cancun II).

7. HvJ EU 7 maart 2018, JOR 2018/144 m.nt. J.H.L. Beckers (E.ON Czech/Dêdouch). 


\section{Maandblad}

Ondernemingsrecht

ká plynárenská. Zij wenst de overige drie aandeelhouders - Dêdouch, Streitberg en Suda (hierna: Dêdouch) - uit te kopen. Naar Tsjechisch recht vergt dat geen rechterlijk vonnis, maar volstaat een besluit van de algemene vergadering, waarin de prijs voor de over te dragen aandelen wordt vastgesteld. De uit te kopen aandeelhouders kunnen vervolgens de meerderheidsaandeelhouder en de vennootschap in rechte betrekken, in welke procedure de rechter moet beoordelen of de in het besluit vastgestelde uitkoopprijs 'billijk' is. In casu bewerkstelligt E.ON het uitkoopbesluit, waarna Dêdouch een procedure start tegen E.ON en de vennootschap. Niet verrassend richten Dêdouchs bezwaren zich tegen de hoogte van de uitkoopprijs.

E.ON beroept zich op de onbevoegdheid van de aangezochte Tsjechische rechter. Ingevolge artikel 4 sub 2 EEX - dat de rechter van de woonplaats van gedaagde aanwijst - zou slechts de Duitse rechter bevoegd zijn om de tegen het Duitse E.ON ingestelde vordering te beoordelen. De Tsjechische rechtbank acht zich evenwel bevoegd op grond van artikel 8 sub 1 EEX, dat - als er meerdere verweerders zijn - de rechter van de woonplaats van één hunner alternatief bevoegd maakt. Dêdouch heeft zijn vordering immers niet alleen tegen E.ON, maar ook tegen de vennootschap ingesteld. Ook in hoger beroep faalt de door E.ON opgeworpen exceptie. Het hof meent evenzo bevoegd te zijn. Naar 's hofs oordeel draait de zaak om de geldigheid van het uitkoopbesluit, zodat het hof exclusieve rechtsmacht toekomt op de voet van artikel 24 sub $2 \mathrm{EEX}^{8}$ De cassatierechter is daarvan niet zo zeker en beslist prejudiciële vragen te richten tot het Hof van Justitie.

Prima facie ligt de toepasselijkheid van artikel 24 sub 2 EEX voor de hand. Dêdouch betwist immers het uitkoopbesluit, zodat de procedure binnen de scope van artikel 24 sub 2 EEX lijkt te vallen. De moeilijkheid zit er echter in dat de door Dêdouch geëntameerde procedure niet kan uitmonden in de ongeldigheid van het uitkoopbesluit. Naar Tsjechisch recht staat de rechter slechts ter beoordeling of de in het uitkoopbesluit vastgestelde prijs billijk is. Komt de rechter tot de conclusie dat dat niet het geval is, dan stelt hij een andere prijs vast, maar dat laat de geldigheid van het uitkoopbesluit onverlet. De rechter vermag niet het uitkoopbesluit op die grond te vernietigen, zo zegt de Tsjechische wet. Betreft het hier dus wel de geldigheid van een besluit in de zin van artikel 24 sub 2 EEX?

\subsection{Beslissing}

Verrassend genoeg antwoordt het Hof van Justitie bevestigend. De Tsjechische rechter is, aldus het Hof, bij uitsluiting bevoegd om de vordering van Dêdouch te beoordelen, nu deze onder artikel 24 sub 2 EEX valt. Het Hof vat het dictum van zijn arrest in opvallend algemene bewoordingen:
'[E]en vordering als in het hoofdgeding, die strekt tot toetsing van de billijkheid van de vergoeding die de meerderheidsaandeelhouder van een vennootschap moet betalen aan de minderheidsaandeelhouders ervan bij gedwongen overdracht van hun aandelen aan deze meerderheidsaandeelhouder, valt binnen de exclusieve bevoegdheid van de gerechten van de lidstaat waar die vennootschap is gevestigd.'

Het Hof getroost zich de nodige moeite om deze beslissing te rechtvaardigen. Allereerst ontdoet het zich van het Tsjechisch recht door erop te wijzen dat de uitleg van de EEX-Verordening niet mag afhangen van keuzes die de nationale wetgever heeft gemaakt (r.o. 34). Dat de onbillijkheid van de uitkoopprijs naar Tsjechisch recht niet leidt tot ongeldigheid van het uitkoopbesluit, doet volgens het Hof niet ter zake. Als hij de uitkoopprijs beziet, toetst de rechter in wezen de geldigheid van het uitkoopbesluit. Stelt de rechter vast dat de prijs te laag is, dan moet hij - in de visie van het Hof - het besluit op dat punt nietig verklaren (r.o. 36-37).

Vervolgens motiveert het Hof zijn beslissing met een beroep op de ratio van artikel 24 sub 2 EEX. Deze bepaling strekt ertoe één rechter bevoegd te maken om aldus tegenstrijdige beslissingen te vermijden (r.o. 38). Bovendien bestaat, aldus het Hof, in casu een nauwe band tussen de Tsjechische rechter en het geding. Niet alleen gaat het om een Tsjechische vennootschap, ook luidt het uitkoopbesluit in het Tsjechisch en is op de vordering Tsjechisch recht van toepassing. De Tsjechische rechter is dan ook, nog steeds volgens het Hof, het best geëquipeerd om van de vordering kennis te nemen (r.o. 39-42). Daarbij komt dat

'(...) de aandeelhouders van een vennootschap, en met name de meerderheidsaandeelhouder, moeten verwachten dat de gerechten van de lidstaat waar deze vennootschap is gevestigd de bevoegde gerechten zullen zijn voor de beslechting van een intern geschil van deze vennootschap inzake de toetsing van de geldigheid van een besluit van een orgaan van deze vennootschap op een bepaald punt'. (r.o. 43)

\subsection{Commentaar}

Meermaals is gepoogd het Hof van Justitie ertoe te verleiden aan artikel 24 sub 2 EEX een ruime uitleg te geven. Tot dusver was dat tevergeefs: steeds onderstreepte het Hof dat artikel 24 sub 2 EEX eng uit te leggen is. Slechts wanneer een geschil sec betrekking heeft op de geldigheid van een besluit of op het

8. De procedure speelde onder art. 22 sub 2 EEX (oud), maar eenvoudigheidshalve spreek ik hier over het op dit punt gelijkluidende art. 24 sub 2 EEX van na de herschikking. 
bestaan van de rechtspersoon, ${ }^{9}$ komt de rechter van de vestigingsplaats van de rechtspersoon exclusieve rechtsmacht toe. Zo overwoog het Hof in Hassett \& Doherty dat een vordering tot vergoeding van schade ontstaan als gevolg van een bestuursbesluit niet binnen het bereik van artikel 24 sub 2 EEX valt. ${ }^{10}$ Ook geschillen waarin de geldigheid van een besluit een voorvraag of een zijdelingse kwestie is, heeft het Hof niet onder artikel 24 sub 2 EEX willen brengen. Het besluit moet het 'hoofdonderwerp' van het geding zijn. Verweert de rechtspersoon zich tegen een aanspraak uit een overeenkomst met de stelling dat het aan die overeenkomst ten grondslag liggende besluit in strijd is met de statuten, dan levert dat verweer nog geen exclusieve bevoegdheid op. ${ }^{11}$ Buiten artikel 24 sub 2 EEX valt evenzo een geschil dat in de kern ziet op schade ontstaan door mededingingsrechtelijke inbreuken. ${ }^{12}$

Uit 's Hofs restrictieve benadering hebben rechtspraak en literatuur veelal afgeleid dat het leeuwendeel van de geschillen binnen een rechtspersoon niet onder artikel 24 sub 2 EEX valt. Er is geen algemeen forum societatis. Zo zou geen exclusieve rechtsmacht bestaan over geschillen met betrekking tot de opzegging van een managementovereenkomst dan wel de gevolgen of de uitvoering van een besluit, ${ }^{13}$ de betaling van dividend, het storten op genomen aandelen, de terugbetaling van op grond van een besluit aan een bestuurder betaalde gelden, een aandeelhoudersovereenkomst, bestuurdersaansprakelijkheid en een afgeleide actie. ${ }^{14}$ In Nederland hebben sommigen evenwel met kracht van argumenten geoordeeld dat de geschillenregeling, de uitkoopprocedure en de enquêteprocedure zich binnen de reikwijdte van artikel 24 sub 2 EEX

9. Overigens valt aan te nemen dat art. 24 sub 2 EEX - dat spreekt van 'vennootschappen of rechtspersonen' - niet alleen van toepassing is binnen de rechtspersonen van Boek 2 BW, maar ook geldt voor personenvennootschappen alsmede voor Europese en publiekrechtelijke rechtspersonen. Vgl. het corporatiebegrip in art. 10:117 onder a BW. In deze zin ook: Th. Rauscher/P. Mankowski, Europäisches Zivilprozess- und Kollisionsrecht EuZPR/EuIPR, Keulen: Otto Schmidt 2016, Art. 24 Brüssel Ia-VO, Rn. 60-62 ('alle Personenverbindungen zu einem gemeinsamen Zweck'), Vlas 2017/216 en Rb. Alkmaar 8 juli 1999, NIPR 1999/279 (Stam/Stam) m.b.t. een maatschap. In HR 18 maart 2011, NJ 2011/219 m.nt. M.V. Polak (Szajak-Combé/Bialek), r.o. 3.6.2 laat de Hoge Raad in het midden of een gemeenschap onder art. 22 sub 2 EEX valt.

10. HvJ EG 2 oktober 2008, NJ 2009/192 m.nt. P. Vlas (Hassett \& Doherty), r.o. 31 .

11. HvJ EU 12 mei 2011, NJ 2011/363 m.nt. M.V. Polak (Berliner Verkehrsbetriebe/JPMorgan), r.o. 44 .

12. HvJ EU 23 oktober 2014, NJ 2015/284 m.nt. L. Strikwerda (FlyLAL/ Lidosta Riga), r.o. 41.

13. HR 26 november 2011, NJ 2011/55 m.nt. P. van Schilfgaarde (Silverlining/Perstorp), r.o. 3.3.3 en 3.4.2.

14. Zie met name J. Kropholler/J. von Hein, Europäisches Zivilprozessrecht, Frankfurt: Recht und Wirtschaft 2011, Art. 22 EuGVO, Rn. 40, Paschalidis 2012/2.20-2.25, Rauscher/Mankowski 2016, Art. 24 Brüssel Ia-VO, Rn. 72 e.v., P. Torremans e.a., Private international law, Oxford: Oxford University Press 2017, p. 224 en Vlas 2017/217, met verwijzingen. bevinden. ${ }^{15}$ Die pleidooien, hoe sympathiek ook, verdragen zich maar moeizaam met de restrictieve lijn die het Hof van Justitie heeft gekozen.

Maar wellicht ligt nu alles anders. Wellicht zet het Hof van Justitie de eerste stap naar een meer rekkelijke lijn. Weliswaar bewijst het Hof lippendienst aan zijn vaste, strikte rechtspraak (r.o. 27 en 33), maar zijn andere overwegingen zijn moeilijk anders te verstaan dan als een verruiming van artikel 24 sub 2 EEX. Niet alleen geeft het Hof een ruimere uitleg aan het besluitbegrip, ook valt de nadruk op die het legt op argumenten als de Gleichlauf en de nauwe band.

Met de eerdere jurisprudentielijn strookt niet dat de Tsjechische procedure over de billijkheid van de uitkoopvergoeding erop neer zou komen dat de rechter 'de geldigheid van het besluit op een bepaald punt' toetst, zoals het Hof in rechtsoverweging 36 overweegt. Naar de eerdere jurisprudentie moest het immers gaan om de formele geldigheid van een besluit, dat wil zeggen de geldigheid van het besluit tegenover eenieder - nietig, vernietigbaar of geldig - moest in het geding centraal staan. Artikel 24 sub 2 EEX vindt immers zijn rechtvaardiging in het feit dat het gewenst is dat één rechter beoordeelt of een besluit tegenover eenieder werkt dan wel niet werkt. ${ }^{16}$ In deze zaak gaat die ratio niet op. De formele geldigheid van het besluit staat niet ter discussie; de rechter kan slechts schadevergoeding toekennen. Dat het Hof bereid is het Tsjechisch recht op dit punt terzijde te schuiven, is veelzeggend. Dat het Hof vervolgens overweegt dat de rechter het besluit partieel nietig moet verklaren als hij de uitkoopvergoeding onbillijk acht, zegt nog meer. De rechter hoeft dat namelijk helemaal niet. Niets dwingt ertoe dat de rechter het uitkoopbesluit in zo'n geval jegens allen nietig acht; er is geen reden om de vergoeding met werking erga omnes toe te kennen. Als één aandeelhouder de vergoeding onbillijk acht en gaat procederen, bindt de beslissing van de rechter andere aandeelhouders niet. En daarin zit geen probleem, zou ik denken. De vrees voor een relatief besluit - een besluit dat jegens de een wel werkt, maar jegens de ander niet - speelt hier niet, en ook het gevaar van tegenstrijdige beslissingen doet zich niet gevoelen. Zijn beroep op de autonome uitleg van de verordening kan kortom niet verhullen dat het Hof artikel 24 sub 2 EEX ruimer opvat dan voorheen. Het begrijpt een procedure onder die bepaling die met de formele geldigheid en met noodzakelijke werking erga omnes weinig van doen heeft.

Een en ander wordt te meer duidelijk voor wie deze casus legt naast die in Hassett \& Doherty. Daartussen zit nauwelijks ver-

15. Zie C.D.J. Bulten, De geschillenregeling ten gronde (diss. Nijmegen; VDHI nr. 108), Deventer: Kluwer 2011, p. 110-115, T. Salemink, Uitkoop van minderheidsaandeelhouders (diss. Nijmegen; VDHI nr. 125), Deventer: Kluwer 2014, p. 8, noot 5 en Hof Amsterdam (OK) 8 september 2008, JOR 2009/127 m.nt. M.W. Josephus Jitta (eTraction), r.o. 3.12. Anders: Asser/Maeijer \& Kroeze 2-I* 2015/238.

16. Zie met name Rauscher 2016, Art. 24 Brüssel Ia-VO, Rn. 57 en 70, de daar vermelde literatuur en HvJ EG 2 oktober 2008, NJ 2009/192 m.nt. P. Vlas (Hassett \& Doherty), r.o. 20. 


\section{Maandblad}

Ondernemingsrecht

schil. Hassett en Doherty waren ieder het slachtoffer van een medische beroepsfout. Met het ziekenhuis kwamen zij een vaststellingsovereenkomst overeen, op grond waarvan hun een schadeloosstelling toekwam. Voor het geval dat het ziekenhuis de uitbetaalde vergoedingen op hen zou wensen te verhalen, vorderen de betrokken artsen dat de Medical Defense Union die rekening zou voldoen. De Medical Defense Union behartigt de belangen van artsen en heeft in dat kader de taak haar leden financieel bij te staan wanneer zij worden aangesproken vanwege een beroepsfout. Het bestuur van de Union besluit evenwel het verzoek van de artsen af te wijzen. De artsen voeren in rechte aan dat dit besluit hun statutaire rechten miskent. Dat lijkt toch de geldigheid van een besluit te betreffen, zodat de zaak onder artikel 24 sub 2 EEX zou vallen. Het Hof van Justitie oordeelt niettemin anders. Volgens het Hof trekken de artsen namelijk niet in twijfel dat het bestuur van de Union bevoegd is om tot afwijzing van hun verzoek te besluiten. Hun vordering zou derhalve niet de geldigheid van een besluit betreffen, maar de uitoefening van een op een besluit gebaseerde bevoegdheid. ${ }^{17}$ Die redenering had het Hof mijns inziens evengoed kunnen toepassen op de Tsjechische uitkoopprocedure, maar het kiest ervoor dat niet te doen.

Opvallend is verder, ik merkte het al op, dat het Hof zijn beslissing motiveert met een uitvoerige verwijzing naar de nauwe band die tussen het geschil en de Tsjechische rechter zou bestaan, en ook naar de Gleichlauf tussen de bevoegde rechter en het toepasselijke recht. Als die aanknopingsfactoren werkelijk de doorslag geven, verbreedt dat de scope van artikel 24 sub 2 EEX aanzienlijk. De uitstoting/uittreding, de enquête en de uitkoop zouden dan sowieso binnenboord zijn. ${ }^{18}$ Hier past niettemin nog wel een slag om de arm, zou ik denken. Hoe nauw verbonden en gelijklopend een geschil ook is, daarin zal een besluit een rol moeten spelen. Hoewel het Hof in deze zaak wat heeft gegoocheld met dit besluitvereiste, blijft artikel 24 sub 2 EEX een geschil veronderstellen dat (wellicht indirect) de geldigheid van een besluit betreft. Bij de genoemde procedures zal daaraan niet steeds kunnen worden voldaan.

Alles tezamen zet het Hof de doelpalen wat verder uit elkaar. Verderop zal ik betogen dat die ontwikkeling geen ongewenste is en dat het Hof nog wat verder zou kunnen gaan (par. 4). Zou het niet gewenst zijn om - zoals advocaat-generaal Wathelet in deze zaak bepleitte ${ }^{19}$ - alle interne geschillen binnen een vennootschap onder artikel 24 sub 2 EEX te vatten?

17. HvJ EG 2 oktober 2008, NJ 2009/192 m.nt. P. Vlas (Hassett \& Doherty), r.o. 26-30

18. Vgl. de in noot 15 genoemde literatuur.

19. A-G Wathelet, conclusie voor HvJ EU 7 maart 2018, JOR 2018/143 (E.ON Czech/Dêdouch), punt 36.

20. HR 8 december 2017, JOR 2018/143 m.nt. A. Knigge en P. Sluijter (Inversiones/Cancun II). Ik bespreek niet alle geschilpunten, met name niet die welke door de Hoge Raad met art. 81 lid 1 Wet RO zijn afgedaan - zie daarvoor de conclusie van A-G Vlas, ECLI:NL:PHR:2017:1098.

\section{Inversiones/Cancun $\mathrm{II}^{20}$}

\subsection{Casus}

Ook andere wegen dan de exclusieve bevoegdheid van artikel 24 EEX kunnen naar het forum societatis leiden. In de Cancun-zaak, waarvan de IPR-aspecten onlangs de Hoge Raad bereikten, speelde (onder andere) de vraag of de Nederlandse rechter zijn bevoegdheid mocht baseren op artikel 8 sub 3 EEX. $^{21}$ Deze bepaling voorziet in een alternatief forum. Wanneer de gedaagde een vordering in reconventie instelt, is de rechter bevoegd die rechtsmacht bezit ten aanzien van de vordering in conventie. Wel moeten, kort gezegd, de vorderingen over en weer voldoende samenhangen.

De Cancun-zaak is bekend. Het dispuut tussen twee families, met als inzet een Mexicaans hotel, ${ }^{22}$ leidde onder meer tot vier - nu al klassiek geworden - enquêtebeschikkingen, zodat ik op deze plaats van een uitvoerige bespreking afzie. ${ }^{23}$ Het hier te bespreken arrest betreft de nasleep van de enquêteprocedure, die was gefinancierd door de uitgifte van aandelen in houdstermaatschappij Cancun II. In de onderhavige zaak vordert Inversiones, aandeelhouder in Cancun II, de vernietiging van het uitgiftebesluit. Cancun II stelt daarop allerhande reconventionele vorderingen in. Zo vordert Cancun II dat de rechter Inversiones gebiedt zich - kort gezegd - aan de enquêtebeschikkingen te houden, onder andere door haar aandelen in Efesyde (de vennootschap waarin het hotel zich bevindt) aan Cancun II te leveren. Voorts vordert Cancun II onder meer de verklaring voor recht dat Inversiones jegens haar onrechtmatig heeft gehandeld. ${ }^{24}$

Welke rechter het uitgiftebesluit kan vernietigen, lijdt geen twijfel. Cancun II is immers een Nederlandse BV, zodat de Nederlandse rechter op grond van het hiervoor besproken artikel 24 sub 2 EEX exclusieve rechtsmacht toekomt. De vraag is evenwel of de Nederlandse rechter evenzo bevoegd is te oordelen over de door Cancun II ingestelde vorderingen in reconventie. Meer precies: vallen deze vorderingen onder artikel 8 sub 3 EEX? Hangen de vorderingen van Cancun II voldoende samen met de vordering tot vernietiging van het uitgiftebesluit?

\subsection{Beslissing}

De Hoge Raad beantwoordt voornoemde vraag bevestigend en volgt daarmee het Gerechtshof Amsterdam. ${ }^{25}$ Artikel 8 sub 3 EEX vereist dat de 'tegenvordering (...) voortspruit uit de

21. De procedure speelde onder art. 6 sub 3 EEX (oud), maar eenvoudigheidshalve spreek ik hier over het op dit punt gelijkluidende art. 8 sub 3 EEX van na de herschikking.

22. Niet zomaar een hotel: m.i. is in de literatuur tot dusver onderbelicht gebleven dat het een 'AAA Four Diamond Resort' betreft, dat 'style, sexiness and sophistication' in zich verenigt, althans volgens www. secretsresorts.com/en_us/resorts/mexico/silversands-riviera-cancun.html.

23. O.a. HR 4 april 2014, NJ 2014/286 m.nt. P. van Schilfgaarde (Cancun).

24. Zie nader r.o. 3.2.2 van 's Hogen Raads arrest.

25. Hof Amsterdam 28 juni 2016, ECLI:NL:GHAMS:2016:2502, r.o. 3.6-3.8 
overeenkomst of uit het rechtsfeit waarop de oorspronkelijke vordering gegrond is'. Het komt erop aan of de vorderingen van Cancun II voortvloeien uit hetzelfde 'rechtsfeit' als die van Inversiones. Volstaat hiervoor, zoals het Hof overwoog, dat alle vorderingen in wezen betrekking hebben op een en hetzelfde geschil over een Mexicaans hotel? Of moeten, zoals het cassatiemiddel voorstaat, ook de vorderingen van Cancun II betrekking hebben op c.q. enig verband houden met het door Inversiones bestreden uitgiftebesluit?

Naar het oordeel van de Hoge Raad heeft de term 'rechtsfeit' een ruime strekking. Het gaat erom, zo overweegt hij, dat de tegenvordering uit 'hetzelfde feitencomplex' voortspruit als de oorspronkelijke vordering (r.o. 3.4.1). Artikel 8 sub 3 EEX moet tenslotte zo worden uitgelegd dat partijen in de gelegenheid zijn hun 'wederzijdse aanspraken met een gemeenschappelijke grond' door dezelfde rechter te doen beslechten (r.o. 3.4.2). Hiermee spreekt de Hoge Raad nagenoeg letterlijk de woorden na van het Hof van Justitie in Kostanjevec, ${ }^{26}$ over welke zaak zo meteen meer. Het een en ander makt dat het niet onjuist is om, zoals het Hof Amsterdam deed, de eis te stellen dat de vorderingen over en weer verknocht zijn. De Hoge Raad verwijst naar het rapport Jenard, de gezaghebbende toelichting op de EEX-Verordening, waaruit blijkt dat artikel 8 sub 3 EEX nu juist verknochtheid op het oog heeft (r.o. 3.4.3). De verordening kiest andere termen, maar dat is alleen omdat het fenomeen van verknochtheid niet in elke lidstaat met zoveel woorden bestaat. ${ }^{27}$ De Hoge Raad verwerpt het cassatieberoep. De Nederlandse rechter heeft rechtsmacht over alle vorderingen in reconventie.

\subsection{Commentaar}

De beslissing is fraai, maar niet evident. De Hoge Raad lijkt een wat ruimere uitleg aan het begrip 'rechtsfeit' te geven dan welke kan worden afgeleid uit het Kostanjevec-arrest van het Hof van Justitie. Voor een goed begrip is enig inzicht in de complexe casus van laatstbedoeld arrest noodzakelijk. Daarin staat een leaseovereenkomst centraal. F\&S vordert achterstallige leasetermijnen van Kostanjevec. De vordering wordt tweemaal toegewezen, maar na een succesvol herzieningsverzoek ligt de zaak weer voor de rechter in eerste aanleg. Nog voordat die oordeelt, schikken partijen. Ondanks de schikkingsovereenkomst doet de rechter in herziening uitspraak: hij wijst de vordering van $\mathrm{F} \& S$ alsnog af. In het hoger beroep, ingesteld door $F \& S$, staan vervolgens twee vorderingen tegenover elkaar. F\&S vordert nog steeds betaling van de leasetermijnen. Kostanjevec vordert in reconventie de terugbetaling van de bedragen die hij in het kader van de schikking heeft betaald op de grondslag van ongerechtvaardigde verrijking. Het Hof van Justitie toont zich bereidwillig: het begrijpt die laatste vordering onder artikel 8 sub 3 EEX. Daarbij speelt evenwel een grote rol dat die vordering voortkomt uit dezelfde overeenkomst als waarop de vordering in conventie is geba-

26. HvJ EU 12 oktober 2016, NJ 2017/154 m.nt. L. Strikwerda (Kostanjevec), r.o. 37.

27. Zie het rapport Jenard, PbEG 1979, C 59/28. seerd. Zonder de leaseovereenkomst, zo overweegt het Hof, zou het niet tot de procedures en de schikking zijn gekomen, en zou F\&S nimmer zijn verrijkt. ${ }^{28}$

In Kostanjevec bestaat de samenhang tussen de twee vorderingen er dus niet slechts uit dat ze feitelijk hetzelfde conflict betreffen dat partijen verdeeld houdt. Het gaat om méér: de vorderingen zijn elk terug te voeren op dezelfde juridische grondslag, dat wil zeggen op de leaseovereenkomst. Het Hof van Justitie benadrukt dit in zijn overwegingen en formuleert zijn slotsom ook in gedetailleerde, sterk op de zaak toegesneden bewoordingen. ${ }^{29}$ Daartegenover staan dan weer de brede, welwillende overwegingen waarop de Hoge Raad zijn beslissing doet steunen, die onderstrepen dat partijen in staat moeten zijn hun wederzijdse aanspraken 'op een gemeenschappelijke grond' in een geschil te doen beslechten. De vraag blijft niettemin of die 'grond' zo rekkelijk mag worden begrepen.

Ik zou de benadering van de Hoge Raad willen onderschrijven. Mijns inziens komt vooral betekenis toe aan het gegeven dat met het criterium in artikel 8 sub 3 EEX volgens het rapport Jenard beoogd is verknochtheid oftewel een zekere samenhang te vereisen, zoals ook veel nationale wetgevers dat doen. ${ }^{30}$ Denk aan het Nederlandse verknochtheid. Naast de 'goede rechtsbedeling' volgt zo een ruime uitleg van artikel 8 sub 3 EEX ook uit het beginsel van equality of arms of, zoals dat in Duitsland heet, het principe van Waffengleichkeit. ${ }^{31}$ De onmogelijkheid om een tegenvordering in hetzelfde geding te brengen jaagt de gedaagde op kosten en beperkt hem daardoor reeds in zijn processuele middelen. Een bijkomstig voordeel is dat artikel 8 sub 3 EEX, zo begrepen, mogelijkheden biedt om geschillen binnen een rechtspersoon in toto door hetzelfde forum te doen beslechten.

Overigens is een ruime uitleg van het begrip 'rechtsfeit' ook van invloed op gevallen waarin een conflict draait om met elkaar verband houdende overeenkomsten. Het woordje 'of in artikel 8 sub 3 EEX betekent mijns inziens dat van twee alternatieve gronden sprake is. ${ }^{32}$ Denk aan overeenkomsten die

28. HvJ EU 12 oktober 2016, NJ 2017/154 m.nt. L. Strikwerda (Kostanjevec), r.o. 38 .

29. HvJ EU 12 oktober 2016, NJ 2017/154 m.nt. L. Strikwerda (Kostanjevec), r.o. 40: '(...) op de eerste vraag [dient] te worden geantwoord dat artikel 6, punt 3, van verordening nr. 44/2001 aldus moet worden uitgelegd dat het door deze bepaling aangewezen gerecht inzake tegenvorderingen bevoegd is om kennis te nemen van een dergelijke vordering op grond van ongerechtvaardigde verrijking, die strekt tot terugbetaling van een bedrag dat overeenstemt met het bedrag dat werd overeengekomen in een kader van een buitengerechtelijke schikking, wanneer deze vordering wordt ingesteld in het kader van een nieuwe rechtsvordering tussen dezelfde partijen na vernietiging van de beslissing waartoe de aanvankelijke rechtsvordering tussen hen had geleid, en waarvan de uitvoering aanleiding had gegeven tot die buitengerechtelijke schikking.'

30. Rapport Jenard, PbEG 1979, C 59/28.

31. Zie M. Stürner, Zur Reichweite des Gerichtsstandes der Widerklage nach Art. 6 Nr. 3 EuGVVO, IPRax 2007, p. 24.

32. In deze zin (impliciet) BGH 12 mei 1993, NJW 1993, 2753, 2754. Zo ook o.a. Rauscher/Leible 2016, Art. 8 Brüssel Ia-VO, Rn. 42 en I. Saenger/H. Dörner, Zivilprozessordnung, Baden-Baden: Nomos 2017, Art. 8 EuGVVO, Rn. 12. 


\section{Maandblad}

Ondernemingsrecht

voortkomen uit dezelfde raamovereenkomst of zijn gesloten in het kader van dezelfde samenwerking. Weliswaar spruit een tegenvordering dan niet voort uit dezelfde overeenkomst, maar wel uit hetzelfde rechtsfeit of - meer precies - uit hetzelfde feitencomplex. Wanneer tussen twee partijen in een duurrelatie, die werken met meerdere overeenkomsten, een conflict ontstaat, zal dat geschil door dezelfde rechter kunnen worden beslecht. Hier ligt mijns inziens vanaf nu wat meer ruimte, althans voor wie het criterium van de Hoge Raad omarmt. $^{33}$

\section{Eén forum voor corporate geschillen?}

Het laat zich hopen dat de rechtsmacht binnen een rechtspersoon komt te liggen bij de rechter in de lidstaat waar de rechtspersoon is gevestigd. ${ }^{34}$ De EEX-Verordening is op dit punt onvolkomen. Een verwijzingsregel voor alle interne geschillen binnen een rechtspersoon ontbreekt. In ieder geval zouden procedures als de enquête, de uitkoop en de geschillenregeling onbetwistbaar onder artikel 24 sub 2 EEX moeten vallen. Zulke geschillen vinden plaats in de schoot van de rechtspersoon, zijn doortrokken van rechtspersonenrechtelijke verhoudingen - en niet zozeer van contractuele - en worden in de regel door het incorporatierecht beheerst. Ze raken allen binnen de rechtspersoon en werken in die zin erga omnes. Ze hebben daarbij niet minder met de rechtspersoon van doen dan een dispuut over een besluit. De beperking tot besluiten is niet alleen moeilijk te begrijpen, ze houdt bovendien ook in de praktijk weinig steek. In de meeste, belangrijkste geschillen is de inzet geen besluit. Veelal heeft het aantasten van een besluit weinig zin, omdat de nietigheid of vernietiging ervan geen gevolg heeft voor een daaropvolgende vertegenwoordigingshandeling. ${ }^{35}$

Voor de uitvoering van besluiten geldt dit alles evenzo. Ook een geschil over de opzegging van een managementovereenkomst als uitvoering van een daartoe strekkend besluit - zoals in Silver Lining ${ }^{36}$ - zou wat mij betreft onder artikel 24 sub 2 EEX moeten worden begrepen. Dat geldt voorts wanneer een aandeelhouder wordt verweten een onrechtmatig besluit te

33. Terughoudender: Cass. (Fr.) 18 februari 1994, JDI 1995, 150, AG Trier 11 maart 2005, IPRax 2007, 21 en - ook na Kostanjevec - de meeste literatuur vermeld in Rauscher/Leible 2016, Art. 8 Brüssel Ia-VO, Rn. 42. In dezelfde zin: Stürner 2007, p. 23.

34. In deze zin ook A-G Wathelet, conclusie voor HvJ EU 7 maart 2018, JOR 2018/143 (E.ON Czech/Dêdouch), punt 23-26, alsook (vooral) R. Geimer, Das Fehlen eines Gerichtsstandes der Mitgliedschaft als gravierender Mangel im Kompetenzsystem der Brüsseler und der Luganer Konvention, in: Festschrift für Helmut Schippel zum 65. Geburtstag, München: C.H. Beck 1996, p. 869 e.v. en M.V. Benedettelli, Brussels I, Rome I and issues of company law, in: J. Meeusen, M. Pertegás \& G. Straetmans (red.), Enforcement of international contracts in the European Union, Antwerpen: Intersentia 2004, p. 247.

35. Zie M.E. Koppenol-Laforce \& M. Zilinsky, De grenzen van art. 22 sub 2 EEX-Vo in het licht van de rechtspraak van het Hof van Justitie, in: F. Ibili, M.E. Koppenol-Laforce \& M. Zilinsky (red.), IPR in de spiegel van Paul Vlas, Deventer: Kluwer 2012, p. 128-129.

36. HR 26 november 2011, NJ 2011/55 m.nt. P. van Schilfgaarde (Silverlining/Perstorp). hebben bewerkstelligd, zoals in het klassieke Nimox-arrest. ${ }^{37}$ En wat te denken van een casus als in Kekk/Delfino? ${ }^{38}$ Daargelaten dat het geschil een ontslagbesluit betrof, zou mijns inziens een dispuut over (de doorwerking van) een aandeelhoudersovereenkomst tot de reikwijdte van artikel 24 sub 2 EEX moeten behoren. Hetzelfde geldt voor de vorderingen over en weer in het boven besproken Inversiones/Cancun II. Zo'n verruiming doet niet slechts recht aan het feit dat dit soort geschillen rechtspersonenrechtelijk van aard zijn, maar maakt ook het beslechten van zogeheten multi-issues-geschillen minder gefragmenteerd. Dat een besluit thans het centrale geschilpunt moet betreffen, staat eraan in de weg dat één rechter een geschil omvattend kan afdoen. ${ }^{39}$

Overigens blijft ook met een ruime uitleg van artikel 24 sub 2 EEX het probleem bestaan dat inzake de vestigingsplaats van de rechtspersoon twee uiteenlopende leren in zwang zijn. Artikel 24 sub 2 EEX bepaalt dat de rechter zijn eigen internationaal privaatrecht toepast, dat wil zeggen de incorporatieleer of de leer van de werkelijke zetel. Een heus forum societatis ligt alleen in het verschiet wanneer aan de tweeslachtigheid van het vestigingsbegrip een einde komt. Een ander 'probleem' - ik zie dat zelf niet als probleem - is dat de exclusief bevoegde overheidsrechter door partijen met een arbitragebeding kan worden gepasseerd. Artikel 24 sub 2 EEX staat in de weg aan een forumkeuze, maar niet aan arbitrage. ${ }^{40}$

Jammer genoeg is het nog niet zover. Eén zwaluw maakt nog geen zomer. $\mathrm{Nu}$ een nieuwe herschikking van de verordening voorlopig niet te verwachten is, valt te hopen dat het Hof van Justitie de lijn doortrekt die het in het behandelde E.ON Czech/Dêdouch voorzichtig heeft gekozen. Natuurlijk kan het Hof uitgesproken afstand nemen van zijn eerdere, strakke jurisprudentie. Aannemelijker is dat het Hof het besluitbegrip ruimer zal vatten. Het kan, onder het mom van een autonome uitleg, een besluit inlezen en aldus beslissen dat een geschil 'in wezen' een besluit betreft. Al helemaal geestverruimend zou het werken wanneer het Hof tot de conclusie komt dat ook negatieve besluiten besluiten zijn. Wanneer in een conflictsituatie besluitvorming stagneert of de verkeerde besluiten worden genomen, betreft het geschil in wezen evenzeer de besluitvorming. ${ }^{41}$ Wordt vervolgd.

37. HR 8 november 1991, NJ 1992/174 m.nt. J.M.M. Maeijer (Nimox). Wanneer zo'n vordering tegen de rechtspersoon wordt ingesteld, geldt ingevolge art. 4 EEX (forum gedaagde) dat de rechter van de plaats van vestiging bevoegd is.

38. Hof Amsterdam 13 januari 2015, JOR 2015/69 m.nt. R.G.J. Nowak (Kekk/Delfino).

39. Vgl. F. Wedemann, Die internationale Zuständigkeit für Beschlussmängelstreitigkeiten, AG 2011, p. 284-285.

40. Rapport Schlosser, PbEG 1979, C 59/93. Zie Benedettelli 2004, p. 248 die (naar wenselijk recht?) evenwel anders betoogt.

41. In deze zin reeds Bulten 2011, p. 110. 